\title{
Mechanisims of asthma and allergic disease - 1073. Image analyses and cell activation of Der p2 in human epithelium
}

Jawji Tsai

From 2nd WAO International Scientific Conference (WISC 2012)

Hyderabad, India. 6-9 December 2012

\section{Background}

House dust mites can cause airway inflammation. Its major allergen Der p2 causes inflammation with functions mimicking myeloid differentiation-2 (MD2). The epithelium activated by Der p2 and its relationship with LPSpromoted MD2/TLR signaling remained obscure.

\section{Objective}

To provide image analyses of Der p2 and MD2 in epithelium.

\section{Methods}

Both nasal polyps and BEAS-2B were used to examine the internalization of Der $\mathrm{p} 2$ in epithelium. The upregulation of MD2 was determined by messenger RNA (mRNA) and protein expression, and confirmed by amino acid sequencing. The cytokine secretions of Interleukin-6/Interleukin-8 (IL-6/IL-8) from epithelium were measured. The effects of Der p2 on BEAS-2B were further investigated by LPS-promoted MD2/TLR signaling and cytokine secretions, and evaluated by antibodies of TLR and inhibitors of transcription factor.

\section{Results}

The expression of MD2 was increased in epithelium of nasal polyps and BEAS-2B after rDer p2 treatment. After co-immunoprecipitation with anti-Der $\mathrm{p} 2$, immuno-reactive MD2 could be identified. Der p2-EGFP could localize in endoplasmic reticulum (ER). In the presence of $\mathrm{rDer} \mathrm{p} 2$, the secretions of IL-6/IL- 8 by BEAS-2B were trivial but augmented by LPS and reduced by anti-MD2. When BEAS-2B was cultured with rDer p2 in conjunction with LPS, the

Department of Medical Research, Taichung Veterans General Hospital, Taiwan

(C) 2013 Tsai; licensee BioMed Central Ltd. This is an Open Access article distributed under the terms of the Creative Commons Attribution License (http://creativecommons.org/licenses/by/2.0), which permits unrestricted use, distribution, and reproduction in any medium, provided the original work is properly cited.
mRNA expression of TLR2 and IL-6/IL-8 were increased. The increments were downregulated by Mitogen-Activated Protein Kinase (MAPK) inhibitors, dexamethasone, calcitriol and neutralizing antibody of TLR2.

\section{Conclusions}

We provided evidences of Der p2 internalization and MD2 upregulation in epithelium. The synergistic effects of Der p2 and LPS on IL-6/IL-8 secretions were through TLR2/ MAPK.MD2 upregulation could serve as an indicator for Der p2-induced airway inflammation.

Published: 23 April 2013

doi:10.1186/1939-4551-6-S1-P70

Cite this article as: Tsai: Mechanisims of asthma and allergic disease -

1073. Image analyses and cell activation of Der p2 in human

epithelium. World Allergy Organization Journal 2013 6(Suppl 1):P70.

Submit your next manuscript to BioMed Central and take full advantage of:

- Convenient online submission

- No space constraints or color figure charges

- Immediate publication on acceptance

- Inclusion in PubMed, CAS, Scopus and Google Scholar

- Research which is freely available for redistribution
- Thorough peer review 